\title{
In vitro digestibility of Paspalum notatum in ruminal fluid of buffaloes (Bubalus bubalis) and bovines (Bos indicus)
}

\author{
Torres, M.'; Zaracho, E. ${ }^{2}$; Aquino, D. ${ }^{3}$; Valiente, O.L. ${ }^{3}$; Criscioni, P. ${ }^{3}$ \\ ${ }^{1}$ Depto.Investig.Cs.Tecnol.; ${ }^{2}$ Depto.Cs.Morfológ.; ${ }^{3}$ Depto.Bromat. \\ Nutr.\& Aliment.Anim., Fac.Cs.Veterinarias, Univ.Nac.Asunción, \\ San Lorenzo, Paraguay. E-mail: patcrife@gmail.com
}

\begin{abstract}
Torres, M.; Zaracho, E.; Aquino, D.; Valiente, O.L.; Criscioni, P.: In vitro digestibility of Paspalum notatum in ruminal fuid of buffaloes (Bubalus bubalis) and bovines (Bos indicus). Rev. Vet. 31: 1, 54-56, 2020. The aim of this experiment was to evaluate the in vitro digestibility coefficients of dry matter (IVDMD) and in vitro organic matter digestibility (IVOMD) of mature Paspalum notatum grass in buffaloes (Bubalus bubalis) and cattle (Bos indicus). For in vitro digestibility, ruminal fluid from one animal of each species was used; animals previously had a period of adaptation to the diet. In vitro digestibility was performed by the Tilley \& Terry method (1963). Significant differences in digestibility were found for both species, IVDMD: $20.31 \%$ vs. $17.91 \%$, standard error mean (SE): 0.6448; IVOMD: $20.30 \%$ vs $15.68 \%$, SE: 1.7429 for buffalos and bovines, respectively.
\end{abstract}

Key words: buffaloes, bovines, Paspalum notatum, in vitro digestibility, ruminal liquid.

\begin{abstract}
Resumen
Torres, M.; Zaracho, E.; Aquino, D.; Valiente, O.L.; Criscioni, P.: Digestibilidad in vitro de Paspalum notatum en líquido ruminal de búfalos (Bubalus bubalis) y cebúes (Bos indicus). Rev. Vet. 31: 1, 54-56, 2020. El objetivo de la investigación fue evaluar los coeficientes de digestibilidad in vitro de la materia seca (DIVMS) y digestibilidad in vitro de la materia orgánica (DIVMO) del pasto Paspalum notatum maduro en búfalos (Bubalus bubalis) y cebúes (Bos indicus). Para la digestibilidad in vitro se utilizó líquido ruminal de un animal de cada especie, los cuales tuvieron previamente un período de adaptación a la dieta. La digestibilidad in vitro se evaluó por el método Tilley y Terry (1963). Diferencias significativas en la digestibilidad fueron encontradas para ambas especies: DIVMS: $20,31 \%$ vs $17,91 \%$, error estándar de la media (EE): 0,6448 y DIVMO: 20,30\% vs 15,68\%, EE: 1,7429 para búfalos y cebúes respectivamente.
\end{abstract}

Palabras clave: búfalos, cebúes, Paspalum notatum, digestibilidad in vitro, líquido ruminal.

\section{INTRODUCTION}

One of the most important factors in animal production is the animal feeding, and therefore it is a challenge to determine the feeding method in relation to animal species and the type of farm used ${ }^{1}$.

In Paraguay, in the last 3 decades due to the use of land for agricultural purposes, it has led to a migration of livestock, from breeding, rearing and finishing of cattle to marginal lands where forage supply and quality are lower and greater risk of seasonal abnegation of the fields, so that the use of species or animal biotypes with better adaptation and greater capacity to use fibrous forages could become a good alternative ${ }^{2}$.

Ruminants are important suppliers of animal protein, and it is the bovine par excellence the most exploited species. However, the water buffalo is considered a viable option for the challenge of meeting the demand

Recibido: mayo 2019 / Aceptado: setiembre 2019 for high-quality food, since they have the ability to adapt to different climates, present high fertility rates and high capacity of utilization of fibrous forages ${ }^{13}$.

Several differences have been observed between buffaloes and cattle in relation to the anatomy and physiology of the digestive system, digestibility and nutrient degradation ${ }^{4,9}$. The bubaline population has grown rapidly as well as its importance in volume of milk produced and quality of meat ${ }^{8}$.

This trend can be observed in our country, where according to the official data of livestock statistics provided by the National Service of Animal Health (SENACSA) ${ }^{16}$, the population of buffaloes in 2010 was 5875 heads and an annual increase approximately $10 \%$ was presented, until reaching 11582 heads in the year 2017.

Taking into account the growing population of the buffalo species at the regional level and the little information about it and its feeding, the objective of this work was to evaluate the in vitro digestibility of 
the dry and organic matter of a forage widely used as Paspalum notatum in this species (comparing it with bovine) and in this way obtain information about its feeding and breeding alternative.

\section{MATERIAL AND METHODS}

Animals and feeding. The experiment was carried out in the Departmen of Bromatology, Nutrition \& Animal Feeding, Faculty of Veterinary Science, National University of Asunción, Paraguay, for which two animals were used, adults, whole males, one of the bubaline species and another of the bovine species, of which extracted ruminal fluid for the study of in vitro digestibility. During the period of habituation (12 days) the animals were kept stabled in pens and fed with $P$. notatum hay, and they were offered water at will.

Experimental procedure. The experiment began with a period of adaptation to the 12-day diet, during which ruminal fluid supplying animals consumed $P$. notatum hay and water ad libitum. The study of in vitro digestibility was performed by the method of Tilley and Terry (1963) ${ }^{18}$, which consists of a 48-hour incubation period in ruminal fluid in a buffer medium corresponding to the first phase and a second one of digestion in hydrochloric acid-pepsin also for 48 hours. The amounts of dry matter (DM) and organic matter (OM) that disappear after incubations will be considered "digested". Before the ruminal fluid extraction, the liquid supplying animals were fasted for $12 \mathrm{~h}$, and 6 repetitions were incubated for each type of sample.

Chemical analysis. The chemical analysis of the grass was carried out by means of methods of Association of Official Analytical Chemists, AOAC International $(2000)^{3}$, for dry matter (DM), ethereal extract (EE), crude proteín (CP), neutral detergent fiber, (NDF), and acid detergent fiber (ADF). The NDF was determinate using sodium sulfite and alpha amylase. The gross energy (GE) was determined by adiabatic calorimeter bomb and the non-fibrous carbohydrates (NFC) content was calculated by difference based on individual chemical analyzes according to National Research Council (NRC, 2001) ${ }^{15}$.

Calculations. The percentage of digestibility of the dry matter and the organic matter in vitro (\% IVDMD and $\%$ IVOMD) was calculated as follows:

\% IVDMD: initial dry matter (residual dry matter of the sample - dry matter residual of the blank) x 100 / initial dry matter.

$\%$ IVOMD: initial organic matter - (organic residual matter of the sample - organic residual matter of the blank) x 100 / initial organic matter.

The NFC (non-fiber carbohydrate) content was calculated with the following equation: 100-NDF-ash-CPEE.
Statistical analysis. The data were analyzed with the analysis of variance with SAS software (2001) ${ }^{17}$.

\section{RESULTS AND DISCUSSION}

Table 1 shows the IVDMD coefficients obtained for bovines and buffaloes, being 2.4\% higher in the latter $(p>0.05)$ the same trend is observed in IVOMD where it was $4.6 \%$ higher $(p>0.05)$. Studies carried out on the rumen metabolism of buffaloes and cattle, highlights that buffaloes present higher concentrations of volatile fatty acid and ammonium in ruminal fluid, which suggests a higher rate of degradation of food by buffaloes ${ }^{9}$. Higher values than those found in this work $47 \%$ IVDMD for buffaloes and $40 \%$ for cattle ${ }^{11}$.

These lower coefficients could be explained by the quality of the grass used, as can be seen in Table 2 of bromatological composition present values of NDF (neutral detergent fiber) around $80 \%$ and $39.4 \%$ of ADF (acid detergent fiber) and whose relative value of forage RVF (relative value of foraje) was $71.62 \%$ which reflects a low forage quality index (Table 3) as well as its ingestion and digestibility potential ${ }^{7}$.

Comparing the characteristics of fermentation and microbial populations of buffalo and cattle, it was

Table 1. In vitro digestibility (\%) of dry matter and organic matter of the P. notatum in buffalos and cattle.

\begin{tabular}{ccccc}
\hline matter & cattle & buffalo & SE & p-value \\
\hline IVDMD & 18.18 & 20.31 & 0.6448 & 0.0055 \\
IVOMD & 15.68 & 20.30 & 1.7429 & 0.0005 \\
\hline
\end{tabular}

IVDMD: in vitro dry matter digestibility; IVOMD: in vitro organic matter digestibility. SE: standard error mean.

Table 2. Chemical composition of Paspalum notatum hay (based on dry matter $\mathrm{g} / \mathrm{kg} \mathrm{MS}$ ).

\begin{tabular}{cc}
\hline Comp.(\% DM) & P. notatum \\
\hline DM & 917 \\
CP & 80 \\
NDF & 756 \\
ADF & 394 \\
EE & 17 \\
GE & 154 \\
NFC & 144 \\
\hline
\end{tabular}

Comp: composition; DM: dry matter; CP: crude protein; NDF: neutral detergent fiber; ADF: acid detergent fiber; EE: eher extract; GE: gross energy (MJ/kg DM); NFC: non fibrous carbohydrate content

Table 3. Relative value of the forage.

\begin{tabular}{cc}
\hline item & P. notatum \\
\hline DMI & 1.58 \\
DMD & 58.18 \\
RVF & 71.62 \\
\hline
\end{tabular}

DMI: potential dry matter ingestion; DMS: potential dry matter digestibility; RVF: relative value of the forage 
found that buffaloes had greater apparent digestibility of DM, OM, CP and ADF than cattle, and stated that the main factor that determined these differences was the type of microbial populations predominant in the bubaline species ${ }^{5}$.

On the other hand, the type of food consumed by the animal that will be a ruminal inoculum donor may have effects on the degradation of OM and fiber fractions more than the species itself ${ }^{2,10}$. For this work, an animal of each species was previously adapted to a diet similar to that used in the experiment, which reduced the impact of the diet on the response variables.

Using lignin as a marker greater $\mathrm{DM}$ and $\mathrm{CP}$ digestibility is observed in buffaloes than in cattle, so we can deduce that buffalo digests nutrients better than bovine ${ }^{12}$.

Other authors indicate that some aspects such as the lower ingestion of the dry matter, the habit of eating more slowly and the lower rate of passage of the food contribute to a slight superiority of the digestibility observed in the buffalo rumen in studies in vivo and in sacco.

However, in in vitro studies the data may not be evident since the methodology has some limitations, for example it does not consider the rate of passage and the variation in dry matter intake ${ }^{14}$.

Digestibility study in situ of Pennisetum purpure$u m$ in buffaloes and bovine zebu showed that the degradation kinetics of the DM was similar in both species, but the effective ruminal degradability was higher in buffaloes in relation to bovines for both forages, DM (38.82 vs $34.58 \%$ ); NDF (33.94 vs $29.15 \%$ ) and ADF (25.96 vs $22.04 \%$ ). This might suggest more efficient ruminal use by buffalo river compared to the zebu ${ }^{6}$.

We can conclude that IVDMD and IVOMD are higher in buffaloes than in bovines, coinciding with other authors. The lower values found in this work could be due to the low quality of the grass. The breeding of buffaloes becomes an interesting alternative production in places where the forage supply is scarce and it is suggested to continue digestibility studies (in vivo and in vitro) with different feeding alternatives.

\section{REFERENCES}

1. Angulo RA, Noguera RR, Berdugo JA. 2005. El búfalo de agua (Bubalus bubalis), un eficiente utilizador de nutrientes: aspectos sobre fermentación y digestión ruminal. Liv Res Rural Develop 17: 67-71.

2. Ayres JF. 1991. Sources of error with in vitro digestibility assay of pasture feeds. Grass \& Forage Sci 46: 89-97.

3. Association of Official Analytical Chemists (AOAC). 2000. Official Methods of Analysis, $18^{\circ}$ ed., Association of Official Analytical Chemists, Arlington, USA.
4. Bartocci S et al. 1997. Solid and fluid of passage rate in buffalo, cattle and sheep fed diets with different forage to concentrate ratios. Livest Prod Sci 52: 201-208.

5. Chanthakhoun V, Wanapat $M$, Kongmun $P$, Cherdthong A. 2012. Comparison of ruminal fermentation characteristics and microbial population in swamp buffalo and cattle. Livestock Sci 143: 172-176.

6. Delgado DC, Rosabal Y, Cairo J. 2005. In situ ruminal degradability of Pennisetum purpureum Cuba CT-115 in commercial river buffaloes and zebu. Cuban J Agric Sci 39: 181-189.

7. FEDNA (Fundación Española para el Desarrollo de la Nutrición Animal). 2010. Tablas de composición y valor nutritivo de alimentos para la fabricación de piensos compuestos, $3^{\mathrm{a}}$ ed., FEDNA., Madrid, España. http://www. fundacionfedna.org/

8. FAO. 2006. Livestock's long shadow: environmental issues \& options. Food \& Agriculture Organization, http:// www.fao.org/docrep/010/a0701e/a0701e00.HTM

9. Franzolin R. 1994. Feed efficiency: a comparison between cattle and buffalo. Buffalo Journal 2: 39-50.

10. Holden LA. 1999. Comparison of methods of in vitro dry matter digestibility for ten feeds. J Dairy Sci 82: 1791-1794.

11. Hussain I, Cheeke PR. 1996. Evaluation of annual ryegrass straw corn juice silage with cattle and water buffalo: Digestibility in cattle vs buffalo, and growth performance and subsequent lactational performance of Holstein heifers. Anim Feed Sci \& Techn 57: 195-202.

12. Lorenzoni WR, Campos J, Garcia JA, Coelho JF. 1986. Ganho de peso, eficiencia alimentar e qualidade da carcaça de novilhos búfalos, nelores, holandeses e mestiços holandes-cebú. Rev Soc Bras de Zoot 15: 486-497.

13. Lourez RR. 2001. Buffalo production systems in American. The buffalo: an alternative for animal agriculture in the third millennium. Anales VI World Buffalo Congress, Maracaibo, Venezuela.

14. Mendes A, Lima FC. 2011. Aspectos nutricionales del búfalo. Rev Tecnol en Marcha 24: 105. http://revistas.tec. ac.cr/index.php/tec_marcha/article/view/169

15. National Research Council (NRC). 2001. Nutrient requirements of dairy cattle, $7^{\text {th }}$ ed., Nat. Acad. Press, Washington, DC.

16. Servicio Nacional de Calidad y Salud Animal (SENACSA). 2019. Estadística Pecuaria 2018. Disponible en: http://www.senacsa.gov.py/

17. Statistical Analysis System (SAS). 2001. User's Guide, version 8.02, Statistical Analysis System Institute Inc., Cary, North Carolina, EEUU, $921 \mathrm{p}$.

18. Tilley A, Terry R. 1963. A two stage technique for the in vitro digestion of forage crops. J Br Grassland Soc 18: 104-111. 